\title{
Additions to the knowledge of genus Stagetus Wollaston, 1861 (Coleoptera, Ptinidae) in the Iberian Peninsula
}

\author{
I. de F. e Silva ${ }^{1 *}$, A. R. M. Serrano ${ }^{1}$ \& P. Zahradník ${ }^{2}$
}

Genus Stagetus Wollaston, 1861 is one of the most speciose within Dorcatominae in the Palaearctic Region. Even though this mycetophagous genus had first been described from two species from the Canary Islands, its geographical range has been proved much wider and is known to occur throughout the world (Español, $1969,1992)$, with 38 species present in the Palaearctic Region (Zahradník, 2007a). At first, the comparative study of this group was based solely on a few morphological characters, but these were found to be unreliable upon the advent of the comparative study of male genitalia done by Español (1969). As such, some older records of European species taken from distant localities in North Africa and Western Asia may well need confirmation. The number of species known to occur in the Iberian Peninsula is also uncertain and there is not much consensus on this matter. Español (1992, 1995) and Viñolas (2002) reported only 6 species, whereas more recently Zahradník (2007a) listed 9, 7 of which occurring in Spain and 3 in Portugal.

In this short contribution some findings on Stagetus are presented, including a new species record, Stagetus byrrhoides (Mulsant \& Rey, 1861), previously unknown from the Iberian Peninsula. First data on the presence of Stagetus puncticollis (Brenske \& Reitter, 1884) in Iberia is shown as well. Furthermore, we contribute to clarify the actual number of Stagetus species known to Iberia up to this day.

Site locations are given in the text by UTM $10 \times 10 \mathrm{~km}$ coordinates and shown in Fig. 1. I.
Silva's material is deposited at Faculdade de Ciências, Universidade de Lisboa. Species names follow Zahradník (2007a).

\section{Stagetus byrrhoides (Mulsant \& Rey, 1861)}

Material EXAMINED: 29SND36 - Azinhaga, Golegã, Ribatejo, Reserva Natural do Paúl do Boquilobo (RNPB); altitude: $20 \mathrm{~m}$ ASL; 16-vii-2002, 1 우 (I. Silva leg., P. Zahradník det.; I. Silva col.); habitat: Cork oak (Quercus suber) stand; collecting method: unbaited pitfall trapping.

29SPB28 - Ribeira de Limas, Santa Maria, Serpa, Baixo Alentejo, Parque Natural do Vale do Guadiana (PNVG); altitude: 50 m ASL; 16-vii-2003, 1 우 (I. Silva leg., P. Zahradník det.; I. Silva col.); habitat: sandy river bank with Nerium oleander and Phragmites communis vegetation; collecting method: unbaited pitfall trapping.

29SPB07 - Algodôr, Mértola, Baixo Alentejo, Parque Natural do Vale do Guadiana (PNVG); altitude: 180 m ASL; 02-vii-2003, $10^{\text {\} , ~ } 1 \text { 우 (I. Silva leg., P. Zahradník det.; I. Silva }$ col.); habitat: Holm oak forest (Quercus ilex); collecting method: unbaited pitfall trapping.

KNOWN DISTRIBUTION: Europe - France, Germany, Italy (including Sicily), Poland and South European part of Russia. Western Asia - Armenia, Azerbaijan, Turkey. North Africa - Algeria, Morocco, Tunisia. Central Asia - Kazakhstan, Turkmenistan, Uzbekistan (Zahradník, 2007a, 2007b).

Comments: It is not clear whether $S$. byrrhoides really occurs in North Africa, since according to Español (1969) the records from this region result from erroneous identifications, mostly of $S$. championi. These records represent the first report of this species for Portugal and the Iberian Peninsula.

\footnotetext{
Centro de Biologia Ambiental e Departamento de Biologia Animal, Faculdade de Ciências da Universidade de Lisboa, Ed. $\mathrm{C} 2,2^{\circ}$ piso, Campo Grande 1749-016 Lisboa, Portugal.

2 Forestry and Game Management Research Institute, CZ-156 04 Praha 5-Zbraslav, Czech Republik.

* Corresponding author: insilva@fc.ul.pt
} 


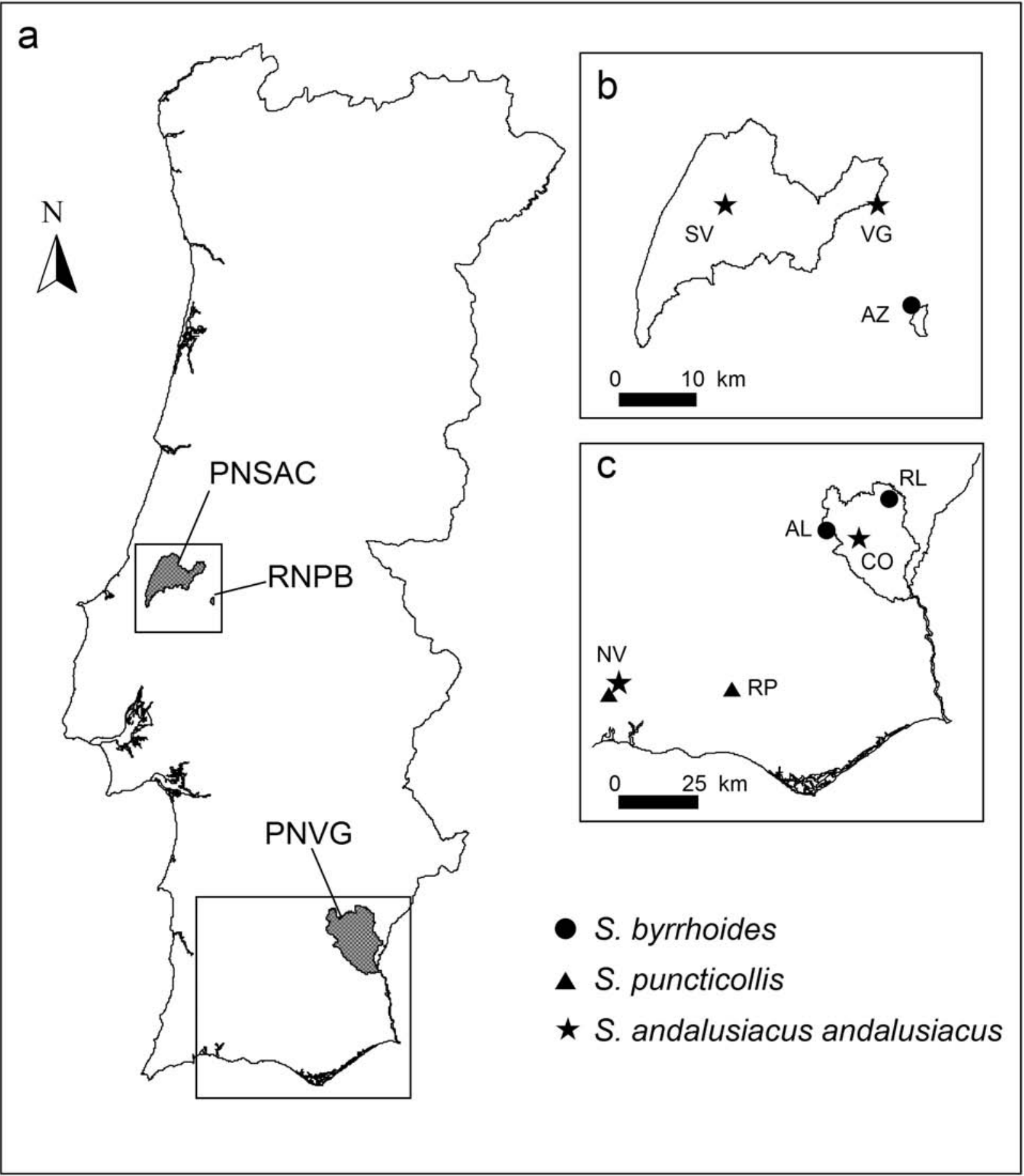

Fig. 1. - Map of Portugal with: a) location of the studied Reserves and, b) and c) site locations of studied Stagetus specimens. Site code explanations: AL- Algodôr, Mértola; AZ- Azinhaga, Golegã; CO- Corredoura, Mértola; NV- Nave, Monchique; RLRibeira de Limas, Serpa; RP- Rocha da Pena, Loulé; SV- Serro Ventoso, Porto de Mós; VG- Vale Garcia, Torres Novas.

Fig. 1. - Mapa de Portugal: a) Situación de las Reservas estudiadas, y b) y c) localidades de procedencia de los ejemplares de Stagetus analizados. 
Stagetus puncticollis (Brenske \& Reitter, 1884)

Material EXAmined: 29SNB32 - Nave, Monchique, Algarve; altitude: $521 \mathrm{~m}$ ASL; 05-xi-2004, 2 specimens (M. Mantic leg., P. Zahradník det. et col.); habitat: mossy, rocky slope with Cork oak (Quercus suber) stand; collecting method: litter, moss and vegetation sifting.

29SNB72 - Rocha da Pena, Loulé, Algarve; altitude: $400 \mathrm{~m}$ ASL; 05-iii-2004, $10^{7}$; 04-xi-2004, 1 \% (M. Mantic leg., P. Zahradník det. et col.); habitat: Quercus coccifera shrubland; collecting method: litter, moss and vegetation sifting.

KNOWN DisTRIBUTION: Europe - Greece, Portugal. Western Asia - Cyprus, Israel, Turkey, Syria. North Africa - Algeria, Morocco, Tunisia (Español, 1969; Zahradník, 2007a, 2007b).

COMMENTS: These specimens represent the first known records for Western Europe. Collection data is presented here for the first time, even though this species had already been listed for Portugal in the Catalogue of Palaearctic Coleoptera (Zahradník, 2007a).

\section{Stagetus andalusiacus andalusiacus (Aubé, 1861)}

Material eXAMINED: 29SND37 - Vale Garcia, Torres Novas, Ribatejo, Parque Natural das Serras d'Aire e Candeeiros (PNSAC); altitude: 270 m ASL; 30-vii-2002, 1 ㅇ ; 08-x-2002, 1 우 (I. Silva leg., det. et col.); habitat: Quercus cocciferaCistus ladanifer shrubland; collecting method: unbaited pitfall trapping.

29SND17 - Serro Ventoso, Porto de Mós, Estremadura, Parque Natural das Serras d'Aire e Candeeiros (PNSAC); altitude: 370 m ASL; 12-iii-2002, 1 \& (I. Silva leg., det. et col.); habitat: Quercus faginea forest; collecting method: unbaited pitfall trapping.

29SPB17 - Guadiana River at "Corredoura", Mértola, Baixo Alentejo, Parque Natural do Vale do Guadiana (PNVG); altitude: $30 \mathrm{~m}$ ASL; 13-viii-2003, $10^{7}$ (I. Silva leg., det. et col.); habitat: sandy river bank with Juniperus turbinata, Quercus ilex and Mediterranean shrubland cover; collecting method: unbaited pitfall trapping.

29SNB32 - Nave, Monchique, Algarve; altitude: 521 m ASL; 05-iii-2004, $10^{7}$ (M. Mantic leg., P. Zahradník det. et col.), 6 specimens (M. Mantic leg., P. Zahradník det.; M. Mantic col.); habitat: mossy, rocky slope with Cork oak (Quercus suber) stand; collecting method: litter, moss and vegetation sifting.

KNOWN DISTRIBUTION: Europe - Portugal, Spain. North Africa - Morocco (Zahradník, 2007a).

COMMENTS: Once thought to be endemic to the Iberian Peninsula (Español, 1969, 1992), this subspecies of $S$. andalusiacus was just recently listed from Morocco by Zahradník (2007a), based on specimens collected in the last century by $\mathrm{C}$. Besuchet. Hitherto recorded from few places in
Andalucia (Almería, Cádiz, Córdoba) and Algarve, the catches further north in Serras d'Aire e Candeeiros (Central Portugal) are noteworthy, being up to now this species' northernmost known locations.

Only these three species listed above are undoubtedly known to occur in Portugal, though in the recent Catalogue of Palaearctic Coleoptera (Zahradník, 2007a) Portugal is included as part of the distribution range of Stagetus pellitus (Chevrolat, 1859). Nevertheless, this is based in an old questionable record of a single female from Northern Portugal (Correa de Barros, 1913; Seabra, 1943; Español, 1969), disregarded by Spanish authors (Español, 1992; Viñolas, 2002). Stagetus sardous (Reitter, 1915) was recently listed from Spain by mistake (Zahradník, 2007a), since this species is still believed to be endemic to Sardinia (Audisio et al., 1995). None of the other species occurring in the Iberian Peninsula ( $S$. championi, $S$. elongatus, $S$. pilula, $S$. franzi and $S$. ferreri) have been found in Portugal to this day. In fact, there are very few citations of these species in Spain and all but $S$. championi's come from the surroundings of Tarragona and Barcelona. This comes as no surprise, since these are the homeland provinces of Francesc Español and Amador Viñolas, respectively, two of the main contributors to the study of Iberian Dorcatominae. Therefore, we believe the knowledge on the actual number of Stagetus species and their distribution ranges within Iberia is still rather incipient. With the present contribution the number of species present in Iberia is raised from 6 to 8,3 species known to exist in Portugal and 6 in Spain.

\section{ACKNOWLEDGEMENTS}

We are grateful to Pedro Cardoso, Nuno Oliveira, PNSAC, RNPB and PNVG for fieldwork assistance. Faria e Silva was supported by Fundação para a Ciência e Tecnologia, through SFRH/BD/6051/2001 PhD grant. Zahradník was supported by the long-term Research Intention of the Czech Ministry of Agriculture (MZe-0002070201). Thanks are also due to Carlos D. Santos for help in the making of the map.

\section{References}

Audisio, P., GobBi, G., Liberti, G. \& Nardi, G., 1995. Coleoptera Polyphaga IX (Bostrichoidea, Cleroidea, Lymexyloidea). In: A. Minelli, S. Ruffo \& S. La Posta (eds.). Checklist delle specie della fauna italiana, 54. Calderini. Bologna. 27 pp.

Correa de BARros, J. M., 1913. Adições aos coleópteros de Portugal. Broteria, Serie Zoologica, 11(2): 105-118. 
EsPaÑol, F., 1969. Notas sobre Anóbidos XXXV: Los Stagetus Woll. del Mediterráneo occidental. Eos, 44: 103-119.

Español, F., 1992. Coleoptera, Anobiidae. In: Fauna Ibérica, vol. 2. M. A. Ramos et al. (eds.). Museo Nacional de Ciencias Naturales, CSIC. Madrid. 195 pp.

SEABRA, A. F., 1943. Contribuições para o inventário da fauna lusitânica. Insecta Coleoptera. Memórias e Estudos do Museu Zoológico da Universidade de Coimbra, 142: 1-153.

VIÑOLAS, A., 2002. Nova aportació al coneixement dels anòbids de la Península Ibèrica (Coleoptera: Anobiidae). Butlletí de la Institució Catalana d'Història Natural, 70: 73-77.

ZAHRADNíK, P., 2007a. Ptinidae (without Gibbinae and Ptininae). In: I. Löbl \& A. Smetana (eds.). Catalogue of Palaearctic Coleoptera, Vol. 4. Apollo Books. Stenstrup: 339-362.
ZAHRADNík, P., 2007b. Fauna Europaea: Anobiidae. In: P. Audisio (ed.). Fauna Europaea: Coleoptera. Fauna Europaea version 1.3. http://www.faunaeur.org
Recibido, 9-V-2008 Aceptado, 29-VII-2008 Publicado, 29-XII-2008 